\title{
The John Innes Horticultural Institution
}

$\mathrm{T}^{\mathrm{H}}$ HE John Innes Horticultural Institution is a private foundation for research on plants. It was founded in 1910 under the will of the late John Innes, a resident of Merton, who died in 1904. The occasion of the present article is the completion of the first twenty-five years of work, which has been marked by the issue of a commemorative pamphlet by the Institu. tion.

John Innes envisaged, in the first place, only a small training school for gardeners, but delay, due to litigation, in the drawing up of the scheme, and an unforeseen increase in the value of the estate, made it possible in 1909 for the trustees to embark upon a larger plan. The scheme as drawn up gave as the objects of the Institution "The promotion of horticultural instruction, experiment and research"; it was to "carry out investigations and research, whether of a practical or scientific nature, into any matters having reference to the growth of trees and plants generally". The Institution was established at Merton, some ten miles from central London. The property consists of about 15 acres of land close to John Innes's residence, the Manor House (now occupied by the Director). In the main garden are the biological and chemical laboratories, offices and library of the Institution, together with thirteen greenhouses and appropriate outbuildings for the garden establishment. The Institution also possesses ten dwelling-houses. The present staff consists of the director, Sir Daniel Hall, with sixteen scientific and seven administrative and technical workers, and forty-five gardeners and manual workers.

The intention of the founder with regard to the training of gardeners is met by the annual appointment, for a period of two years, of six student gardeners, who are paid a maintenance grant. These students are men of about twenty years of age, who must have had four years' gardening experience. They are accepted from all parts of the country. Lectures are arranged for them during the winter season, and they get a varied training in practical work. For the benefit of these students, a representative collection of indoor and outdoor plants is kept up. Since the foundation of the Institution, ninety gardeners have passed through this training. Of the former gardeners, sixteen are now in posts abroad, six are horticultural instructors in the county services and a large number are on the staffs of public parks and botanic gardens.
The trustees in 1909 appointed the late William Bateson to be the first director. Bateson having initiated the study of genetics in Great Britain, naturally turned his attention chiefly to plant breeding, though provision was made for cognate branches of study. The plants investigated in the early days included Primula sinensis, $P$. kewensis, Pisum sativum, Lathyrus odoratus, Begonia, Pelargonium, Beta, Linum, various fruit trees and a large range of forms showing variegation and somatic segregation. Four years after the work had begun, it was dislocated by the outbreak of the Great War, and came almost to a standstill in 1917.

After the War, when the threads were gathered together again, Bateson became converted to the importance of chromosome studies in connexion with genetics, and in 1922 he appointed W. C. F. Newton to the staff. Newton introduced a technique largely his own, and was able to solve problems of chromosome behaviour which had evaded previous workers on plant material. $\mathrm{He}$ found an apt pupil and ally in C. D. Darlington, who took charge of the cytological work on Newton's early death in 1927.

On Bateson's death in 1926, the directorship passed to Sir Daniel Hall, who maintained the general trend of the work, appointing J. B. S. Haldane to take charge of the genetics, and installing a biochemist. Research was continued on several experiments of long standing, including Pisum sativum, Mendel's classical subject, and Primula sinensis, which has a continuous genetic history since 1903, when it was first used as an experimental plant by Gregory and Bateson at Cambridge. Other genetical investigations were begun or extended : by J. Philp (now at Cairo) on Newton's poppy material ; by C. J. Huskins (now at Montreal) on wheat and oats ; by F. W. Sansome (now at Manchester) on Lycopersicum; by W. J. C. Lawrence (now curator) on Dahlia; with many other smaller problems. In a different branch of work, D. M. Cayley and A. W. McKenny Hughes discovered the virus origin of 'breaking' in tulips.

A considerable share of the experimental ground is taken up by the fruit department, the slow. maturing material of which needs a long period of cultivation. M. B. Crane has been in charge of this work since 1919. The experiments are planned from a theoretical point of view, but have several very practical bearings, particularly as regards cross-pollination and the improved varieties 
which arise in the course of experiment. Government grants have recently allowed the Institution to engage two assistant pomologists to train under Crane's direction. The Institution is co-operating with various outside bodies, which are growing the new varieties of fruit trees and bushes to test their commercial value on a larger scale than could be done at Merton. A blackberry under the varietal name "John Innes" was recently put on the market through the medium of a trade firm.

The close co-ordination of genetics and cytology begun in 1922 has been continued and extended wherever possible, and is an essential feature of the Institution's method. In addition, there has grown up in the last ten years a school of pure cytology, developing its own special technique for studying heredity and variation and using as experimental material whatever organisms, plant or animal, lend themselves to the problems under investigation. In the last few years, with the advent of R. Scott-Moncrieff, a co-ordination of genetics with the biochemistry of flower-colour has begun, while the cytologists have been using X-ray technique in the solution of their special problems, apart from the use of such methods to induce mutations for genetic study. Sansome has collaborated with the Lister Institute on problems of comparative vitamin $\mathrm{C}$ content in diploid and tetraploid strains of Solanum Lycopersicum.

The Institution has always welcomed visitors from home or abroad who were desirous of taking part in its work or carrying on suitable investigations of their own. There is room for about ten visitors in the various laboratories. Since 1910, some $\mathbf{1 7 6}$ men and women from all over the world have taken part in the scientific work of the Institution, and some six hundred scientific papers and communications have been published. The Institution was recognised in 1931 as a School of the University of London for higher degrees, though it does not accept students specifically to train for their Ph.D. It undertakes no formal teaching, but every two years or so a short course is organised in the summer (July 13-25 this year). On these occasions about forty lectures are given on the special studies of the Institution, and the course is open without fee to members of university and research station staffs and post-graduate students. The summer course is held in the hope of stimulating interest in genetics and cytology, which are as yet little encouraged in the universities, in the hope that these actively growing branches of science may come to take their place in the academic syllabus, and enable teaching to keep pace with research.

\section{The Total Solar Eclipse of June I9}

\section{Preliminary Reports}

\begin{abstract}
$\mathrm{A}^{\mathrm{T}}$ the time of going to press, the available information indicates that the observations of the total solar eclipse of June 19 were unusually satisfactory. By the kindness of Prof. B. P. Gerasimovič we have received news to the effect that at five out of the six stations from which he had received reports, the programmes were successfully carried out. The other-at Kustanay, where the Astronomical Observatory of Moscow, the National Geographic Society of Washington, and the Paris Observatory, were represented-unfortunately experienced rain. "In total, extremely successful eclipse" is Prof. Gerasimovič's summing-up.

The five successful stations were as follows:
\end{abstract}

(I) At Beloretchenskaya, where the Astronomical Observatory of Kharkov, the French Astronomical Society and the Leyden Astronomical Observatory were working.

(2) At Ak Boulak, near Orenburg. Here the Astronomical Observatory of Poulkovo and the Harvard College Observatory had planned extensive spectroscopic observations of the chromosphere and corona in the ultra-violet and infra-red, and the programmes included the use of both fixedand moving-plate cameras.

(3) At Sara, also near Orenburg, where a second expedition from Poulkovo and parties from the Astrophysical Observatory at Arcetri and the Astronomical Society of Czechoslovakia had prepared for further spectroscopic observations and direct photography of the corona.

(4) At Omsk, where a third group of observers from Poulkovo and expeditions from the observa. tories of Kyoto and Poland, as well as the British party under Prof. J. A. Carroll, were stationed. The programmes here included spectrophotometry and the study of polarisation phenomena, interferometric observations of chromospheric lines and internal motions in the corona, in addition to further direct photography of the corona and an attempt to obtain more complete records of the infra-red coronal spectrum.

(5) At Botchkarevo, where a party from the local observatory was engaged. 